The Influence of Organizational Commitment on Job Performance with OCB (Organization Citizenship Behavior) as Moderating Variables in Educators Salatiga City Private Vocational High School

\title{
Pengaruh Komitmen Organisasi Terhadap Prestasi Kerja dengan OCB (Organization Citizenship Behavior) sebagai Variabel Moderating pada Tenaga Pendidik SMK Swasta Kota Salatiga
}

\author{
Mada Adi Wibowo ${ }^{1}$, Rina Sari Qurniawati ${ }^{2}$ \\ Sekolah Tinggi Ilmu Ekonomi (STIE) AMA Salatiga, Jalan Diponegoro 39, Salatiga, Indonesia \\ Email: mada.adi.wibowo@stieama.ac.id
}

\begin{abstract}
This study aims to examine the effect of Organizational Commitment on Work Performance with Organization Citizenship Behavior (OCB) as a Moderating Variable for Salatiga City Private Vocational School Teachers. In this study, Organization Citizenship Behavior $(O C B)$ is positioned as a moderating variable which becomes a variable that strengthens or weakens the influence of Organizational Commitment on Work Performance. The sample in this study were 127 private vocational school teachers in the city of Salatiga. The sampling technique used was purposive sampling, where this technique uses a way of determining specific characteristics that are in accordance with the research objectives. The data collection method used survey method and data analysis technique used absolute value difference regression analysis.
\end{abstract}

The results show that Affective, Normative and Sustainable Commitment has a positive effect on Job Performance, Organization Citizenship Behavior $(O C B)$ has a positive effect on Job Performance and Organization Citizenship Behavior (OCB) strengthens the positive relationship between Affective, Normative and Sustainable Commitment to Work Performance so it can be concluded that the Organization Citizenship Behavior (OCB) which is owned by Educators at the Salatiga City Private Vocational School is able to strengthen the positive relationship between Organizational Commitment to Work Performance.

keywords: Organizational Commitment, Organization Citizenship Behavior (OCB), Job Performance.

Abstrak

Penelitian ini bertujuan menguji pengaruh Komitmen Organisasi terhadap Prestasi Kerja dengan Organization Citizenship Behavior $(O C B)$ sebagai Variabel Moderating pada Tenaga Pendidik SMK Swasta Kota Salatiga. Dalam penelitian ini Organization Citizenship Behavior (OCB) diposisikan sebagai variabel moderating yang menjadi variabel memperkuat atau memperlemah pengaruh Komitmen Organisasi terhadap Prestasi Kerja. Sampel dalam penelitian ini adalah Tenaga Pendidik SMK Swasta di Kota Salatiga yang berjumlah 127 Orang. Teknik sampling yang digunakan adalah purposive sampling dimana teknik ini menggunakan cara mentapkan ciri-ciri khusus yang sesuai dengan tujuan penelitian. Metode pengumpulan data menggunakan metode survei dan teknik analisis data menggunakan analisis regresi selisih nilai mutlak.

Hasil penelitian menunjukkan bahwa Komitmen Afektif, Normatif dan Berkelanjutan berpengaruh positif terhadap Prestasi Kerja, Organization Citizenship Behavior (OCB) berpengaruh positif terhadap Prestasi Kerja serta Organization Citizenship Behavior $(O C B)$ memperkuat hubungan positif antara Komitmen Afektif, Normatif dan Berkelanjutan terhadap Prestasi Kerja sehingga dapat disimpulkan bahwa Organization Citizenship Behavior $(O C B)$ yang dimiliki oleh Tenaga Pendidik pada SMK Swasta Kota Salatiga mampu memperkuat hubungan positif antara Komitmen Organisasi Terhadap Prestasi Kerja.

Kata Kunci : Komitmen Organisasi, Organization Citizenship Behavior (OCB), Prestasi Kerja.

\section{PENDAHULUAN}

Dalam dunia Pendidikan, Tenaga Pendidik berkewajiban menciptakan suasana pendidikan yang bermakna, menyenangkan, kreatif, dinamis, dan dialogis, mempunyai komitmen secara profesional untuk meningkatkan mutu pendidikan, dan memberi teladan dan menjaga nama baik lembaga, profesi, 
dan kedudukan sesuai dengan kepercayaan yang diberikan kepadanya (UU No. 20 tahun 2003 pasal 40 tentang Sistem Pendidikan Nasional). Guru/Tenaga Pendidik adalah salah satu komponen esensial dalam suatu sistem pendidikan maka peran, tugas dan tanggung jawab guru sangat penting dalam mewujudkan tujuan pendidikan nasional yaitu mencerdaskan kehidupan bangsa. Menurut Mangkunegara (2009:67) prestasi kerja adalah hasil kerja secara kualitas dan kuantitas yang dicapai oleh seseorang pegawai dalam melaksanakan tugasnya sesuai dengan tanggung jawab yang diberikan kepadanya. Peran komitmen organisasi dari tenaga pendidik sangat diperlukan dimana komitmen organisasional merupakan tanggapan afektif terhadap organisasi. Robbins (2008:69) Komitmen organisasi adalah suatu keadaan dimana seorang karyawan memihak pada suatu organisasi dan tujuantujuannya, serta berniat memelihara keanggotaannya itu. Dalam konteks yang sama pula, selain komitmen organisasi dari tenaga pendidik adalah perilaku kewarganegaraan organisasi atau organizational citizenship behavior dimana Perilaku proporsial atau tindakan ekstra yang melebihi deskripsi peran yang di tentukan dalam organisasi itu disebut sebagai organizational citizenship behavior Sedarmayanti (2011 : 267). Oleh karena itu, organisasi berkepentingan dengan berkembangnya sumber daya manusia yang memiliki organizational citizenship behavior.

Berdasarkan observasi awal bulan Juli 2019 dibeberapa sekolah swasta di Kota Salatiga. Terdapat temuan persaingan sekolah - sekolah swasta apalagi ditambah dengan biaya yang sepenuhnya dari peserta didik membuat sekolah swasta bersaing dengan sekolah swasta bahkan negeri dalam memberikan pelayanan yang sebaik-baiknya demi kepuasan dan kepercayaan calon peserta didik serta orang tua peserta didik. Hal ini menjadi tolak ukur keberhasilan sekolah untuk tetap bertahan di persaingan yang semakin ketat. Dimana penelitian sebelumnya tahun 2018 dengan judul pengaruh kepemimpinan transformasional, komitmen organisasi dan kepuasan kerja terhadap OCB pada tenaga pendidik dan tenaga kependidikan SMK N 2 Salatiga melalui tanggapan responden bahwa komitmen organisasi pada tenaga kependidikan yang bukan ASN menyatakan mereka tidak akan bertahan lama karena ikatan emosional, gaji, kewajiban terhadap organisasi di Instansi tersebut. Hal ini mendasari peneliti untuk melakukan penelitian lebih lanjut pada Tenaga Pendidik SMK Swasta Kota Salatiga.

\section{TINJAUAN PUSTAKA}

Dalam (Sedarmayanti : 2015) Konsep OCB pertama kalinya didiskusikan dalam literatur penelitian organisasional pada tahun 1980 (Bateman \& Organ, 1983; Smith et., al yang dikutip oleh Bienstock et al 2003:360), Robbins mengemukakan bahwa OCB merupakan perilaku pilihan yang tidak menjadi bagian dari kewajiban kerja formal seorang pegawai, namun mendukung berfungsinya organisasi tersebut secara efe Menurut Organ, OCB adalah perilaku individu yang bebas, tidak secara langsung atau eksplisit diakui dalam sistem pemberian penghargaan dan dalam mempromosikan fungsi efektif organisasi. Menurut Luthans (2006: 251), Perilaku Sosial Organisasi atau lebih dikenal dengan istilah organizational citizenship behavior merupakan perilaku individu yang bebas memilih, tidak diatur secara langsung atau eksplisit oleh sistem penghargaan formal, dan secara bertingkat mempromosikan fungsi organisasi yang efektif.

Ada lima kategori utama Organizational Ctizenship Behavior menurut Dennis W. Organ (dalam Allison dkk, 2001 : 2) dan terus menjadi dimensi yang paling umum diuji dalam penelitian modern, antara lain :

1. Altruism, yang di definiskan sebagai semua perilaku sukarela yang memiliki dampak terhadap orang lain tertentu yang terkait dengan tugas atau masalah dalam organisasi.

2. Conscienctiousness, yaitu meliputi bergerak atau melakukan sesuatu melebihi persyaratan minimum yang diperlukan pada peran pekerjaan.

3. Sportmanship, yang di deskripsikan sebagai menghindari mengeluhkan keluhan kecil, mencerca hal hal kecil yang nyata atau yang sifatnya angan-angan.

4. Courtesy, yang berarti memelihara rekan kerja tetap memperoleh informasi mengenai hal-hal yang relevan bagi mereka. Sebagian pegawai memiliki tendensi menyimpan fakta-fakta yang relevan dan menjaga rahasia peristiwa-peristiwa tertentu. 
5. Civic Virtue, yang meliputi partisipasi secara bertanggung jawab dalam kehidupan politis organisasi, seperti menghadiri pertemuan, membahas isu-isu organisasi di luar waktu kerja, dan menyuarakan keprihatinan.

Robbins (2008:69) dalam perilaku organisasi, komitmen organisasi merupakan komponen dari perilaku. Komitmen organisasi adalah suatu keadaan dimana seorang karyawan memihak pada suatu organisasi dan tujuan-tujuannya, serta berniat memelihara keanggotaannya itu. Menurut Luthans (2011 : 147) komitmen organisasi sebagai keinginan kuat untuk tetap sebagai anggota organisasi tetentu, keinginan untuk berusaha keras sesuai keinginan organisasi, dan keyakinan tertentu, dan penerimaan nilai dan tujuan organisasi.

Berdasarkan pengertian dan pernyataan di atas, dapat ditarik kesimpulan bahwa komitmen organisasi adalah sikap kerja dalam wujud keinginan, kemauan, dedikasi, loyalitas, dan kepercayaan yang kuat yang menunjukkan keinginan tetap menjadi bagian anggota organisasi dengan mau menerima nilai dan tujuan organsisasi, dan bekerja atas nama atau untuk kepentingan organisasi.

Ada tiga komponen utama mengenai komitmen organisasi menurut Robbins, (2008:101) yaitu:

1) Affective commitmen (komitmen afektif), terjadi apabila pegawai ingin menjadi bagian dari organisasi karena adanya ikatan emosional atau psikologis terhadap organisasi.

2) Continuance commitmen (komitmen berkelanjutan) muncul apabila pegawai tetap bertahan pada suatu organisasi karena membutuhkan gaji dan keuntungan-keuntungan lain, atau pegawai tersebut tidak menemukan pekerjaan lain.

3) Normative commitmen (komitmen normatif) timbul dari nilai-nilai diri pegawai. Pegawai bertahan manjadi anggota suatu organisasi karena memiliki kesadaran bahwa komitmen terhadap organisasi tersebut merupakan hal memang harus dilakukan.

Prestasi kerja adalah suatu hasil kerja yang dicapai seseorang dengan melaksanakan tugas yang dibebankan kepadanya yang didasarkan atas kecakapan, pengalaman, kesungguhan, serta waktu (Hasibuan,2008:94). Menurut Mangkunegara (2009:67) prestasi kerja adalah hasil kerja secara kualitas dan kuantitas yang dicapai oleh seseorang pegawai dalam melaksanakan tugasnya sesuai dengan tanggung jawab yang diberikan kepadanya.Unsur-unsur yang dinilai dari prestasi kerja adalah kualitas kerja, kuantitas kerja, keandalan, dan sikap. Kualitas kerja terdiri dari ketepatan, ketelitian, keterampilan, dan kebersihan. Kuantitas kerja terdiri dari output dan penyelesaian kerja dengan ekstra. Keandalan terdiri dari mengikuti intruksi, inisiatif, kehati-hatian, kerajinan, dan sikap terdiri dari sikap terhadap perusahaan, karyawan lain, dan pekerjaan serta kerja sama. Dari beberapa pengertian prestasi kerja yang dikemukakan para ahli di atas dapat disimpulkan bahwa prestasi kerja adalah hasilupaya atau kesungguhan seseorang dalam melaksanakan suatu pekerjaan yang dipercayakan kepadanya dengan kecakapan, pengalaman, dan kesungguhannya sesuai dengan tanggung jawab yang telah diberikan kepadanya.

\section{METODE}

\section{Waktu dan Tempat Penelitian}

Penelitian ini akan dilaksanakan selama 3,5 bulan, yaitu sejak Mei hingga Pertengahan September 2020. Pelaksanaan penelitian dilakukan di 3 SMK Swasta yaitu SMK Saraswati, SMK Muhammadiyah dan SMK PGRI 2 Kota Salatiga dan Analisis data dilakukan di Sekolah Tinggi Ilmu Ekonomi AMA Salatiga.

\section{Metodologi Penelitian}

Penelitian ini bersifat kuantitatif, yang terbagi menjadi dua tahap, yaitu tahap pertama adalah penelitian pendahuluan dimana tim peneliti melakukan pengumpulan data berupa observasi dan wawancara dan tahap kedua adalah penelitian utama dimana metode pengumpulan data memberikan kuesioner via google form dan analisis data. 


\section{Penelitian Pendahuluan (Instrumen Validasi \& Instrumen Survei)}

Penelitian Pendahuluan (instrumen validasi) dilakukan dengan cara observasi dan wawancara terhadap Tenaga Pendidik di 3 SMK Swasta yakni SMK Saraswati, SMK Muhammadiyah dan SMK PGRI 2 Kota Salatiga Tahapan pelaksanaan adalah sebagai berikut:

a) Tahap Pertama Instrumen Validasi b) Tahap kedua Instrumen Validasi c) Tahap Ketiga yaitu Instrumen Survei

\section{Penelitian Utama (Penyajian data dan Analisis Data)}

Setelah kuesioner diyakini tepat saat akan melakukan survei tentang Komitmen Organisasi, OCB (Organization Citizenship Behavior) dan Prestasi Kerja maka tim lanjut melakukan kegiatan penyajian data dan analisis data sebagai berikut :

1) Melakukan uji validitas dan reliabilitas data

2) 2) Uji Asumsi Klasik

3) 3) Uji Regresi dengan Uji Nilai Selisih Mutlak

4) Melakukan Uji Hipotesis (Uji t)

5) Melakukan Uji Hipotesis (Uji F)

6) Melakukan Uji Koefisien Determinasi

\section{HASIL PENELITIAN}

Dalam penelitian ini peneliti sajikan data yang dibutuhkan. Populasi yang peneliti ambil sebagai objek penelitian adalah responden yang telah mengisi kuesioner yang diberikan peneliti, dimana responden itu adalah Tenaga Pendidik dari SMK Swasta di Kota Salatiga yaitu SMK Saraswati, SMK Muhammadiyah dan SMK PGRI 2 Salatiga, Peneliti mengambil sampel sebanyak 127 responden.

\section{Analisis Data}

\section{1) Uji Validitas}

Uji validitas digunakan untuk mengukur tingkat ketepatan suatu instrumen dalam kuesioner. Tinggi rendahnya validitas instrumen menunjukkan sejauh mana instrumen tersebut dapat menggambarkan dan menjelaskan variabel yang diteliti untuk mengukur apakah kuesioner tersebut valid atau tidak maka akan dilakukan pengujian validitas dengan jumlah sampel 127 orang.

Berikut hasil perhitungan dengan SPSS, diperoleh hasil sebagai berikut:

\section{Tabel 1}

\section{Hasil Uji Validitas Kuesioner}

\begin{tabular}{|l|l|l|l|l|}
\hline \multirow{2}{*}{ No. } & Variabel & r hitung & $\begin{array}{c}\mathrm{r} \text { table } \\
5 \%\end{array}$ & \multicolumn{1}{|c|}{ Keterangan } \\
\hline \multirow{2}{*}{1.} & \multirow{2}{*}{ Komitmen Afektif $\left(\mathrm{X}_{1}\right)$} & 0,823 & 0,1743 & Valid \\
\cline { 3 - 5 } & & 0,804 & 0,1743 & Valid \\
\hline
\end{tabular}


Vol 1, No 1 (2021) ; p.67-79;-http://e-journal.stie-aub.ac.id/index.php/probank ISSN : 2252-7885 (cetak)

\begin{tabular}{|c|c|c|c|c|}
\hline & & 0,763 & 0,1743 & Valid \\
\hline & & 0,581 & 0,1743 & Valid \\
\hline \multirow{4}{*}{2.} & \multirow{4}{*}{ omitmen Berkelanjutan $\left(\mathrm{X}_{2}\right)$} & 0,849 & 0,1743 & Valid \\
\hline & & 0,768 & 0,1743 & Valid \\
\hline & & 0,793 & 0,1743 & Valid \\
\hline & & 0,544 & 0,1743 & Valid \\
\hline \multirow{4}{*}{3.} & \multirow{4}{*}{ mitmen Normatif $\left(\mathrm{X}_{3}\right)$} & 0,739 & 0,1743 & Valid \\
\hline & & 0,770 & 0,1743 & Valid \\
\hline & & 0,696 & 0,1743 & Valid \\
\hline & & 0,796 & 0,1743 & Valid \\
\hline \multirow{5}{*}{4.} & \multirow{5}{*}{$\begin{array}{l}\text { Organization Citizenship Behavior } \\
(\text { OCB }) /(\mathrm{M})\end{array}$} & 0,599 & 0,1743 & Valid \\
\hline & & 0,739 & 0,1743 & Valid \\
\hline & & 0,717 & 0,1743 & Valid \\
\hline & & 0,713 & 0,1743 & Valid \\
\hline & & 0,753 & 0,1743 & Valid \\
\hline \multirow{4}{*}{5.} & \multirow{4}{*}{ Prestasi Kerja (Y) } & 0,815 & 0,1743 & Valid \\
\hline & & 0,811 & 0,1743 & Valid \\
\hline & & 0,829 & 0,1743 & Valid \\
\hline & & 0,719 & 0,1743 & Valid \\
\hline
\end{tabular}

Sumber : Hasil pengolahan data 2020 dengan SPSS

Hasil uji validitas menunjukkan bahwa nilai $r$ hitung antara jawaban responden di setiap butir pertanyaan dengan nilai total jawaban responden menghasilkan nilai $r$ hitung $>$ dari $r$ tabel sehingga kelima variabel dinyatakan valid.

\section{2) Uji Reliabilitas}

Uji reliabilitas digunakan untuk melihat sejauh mana hasil suatu pengukuran dapat dipercaya. Hasil penelitian dikatakan reliabel apabila terdapat kesamaan dalam waktu yang berbeda pada subjek yang sama. Pengujian keandalan dalam penelitian ini dilakukan dengan alat analisis scale yang ditunjukkan oleh nilai alpha cronbach > 0,7. Berdasarkan hasil uji SPSS diperoleh hasil sebagai berikut: 
Tabel 2

\begin{tabular}{|l|l|l|l|}
\hline \multicolumn{1}{|c|}{ Hasil Pengujian Uji Reliabilitas } \\
\hline Variabel & Cronbach Alpha & $\begin{array}{l}\text { Alpha } \\
\text { Pembanding }\end{array}$ & Keterangan \\
\hline Komitmen Afektif $\left(\mathrm{X}_{1}\right)$ & 0,730 & 0,7 & Reliabel \\
\hline Komitmen Berkelanjutan $\left(\mathrm{X}_{2}\right)$ & 0,722 & 0,7 & Reliabel \\
\hline Komitmen Normatif $\left(\mathrm{X}_{3}\right)$ & 0,727 & 0,7 & Reliabel \\
\hline $\begin{array}{l}\text { Organization Citizenship Behavior } \\
(\text { OCB }) /(\mathrm{M})\end{array}$ & 0,744 & 0,7 & Reliabel \\
\hline \begin{tabular}{l} 
Prestasi Kerja (Y) \\
\hline
\end{tabular} & 0,802 & 0,7 & Reliabel \\
\hline
\end{tabular}

Sumber : Hasil pengolahan data 2020 SPSS

Berdasarkan hasil uji reliabilitas dengan menggunakan SPSS sebagaimana tabel diatas, menunjukkan bahwa nilai alpha hitung lebih besar dari alpha tabel yaitu 0,70. Dengan demikian, semua variabel-variabel yang digunakan dalam penelitian ini reliabel, sehingga dapat terus digunakan untuk analisis selanjutnya.

3) Uji Asumsi Klasik

a. Uji Normalitas Data

Uji normalitas bertujuan untuk menguji apakah dalam model regresi, variabel pengganggu atau residual memiliki distribusi normal atau tidak. Dari hasil uji Kolmogorov-Smirnov menunjukkan bahwa nilai Kolmogorov-Smirnov Z pada unstandardize residual sebesar 1,016 dengan $p$ value 0,253 sehingga dapat diartikan bahwa data terdistribusi normal karena $p$ value $>0,05$. Normalitas data juga dapat dilihat dari Normal P-P Plot of Regression Standardize Residual dimana pada grafik tersebut data menyebar disekitar garis diagonal yang mengikuti arah garis diagonal.

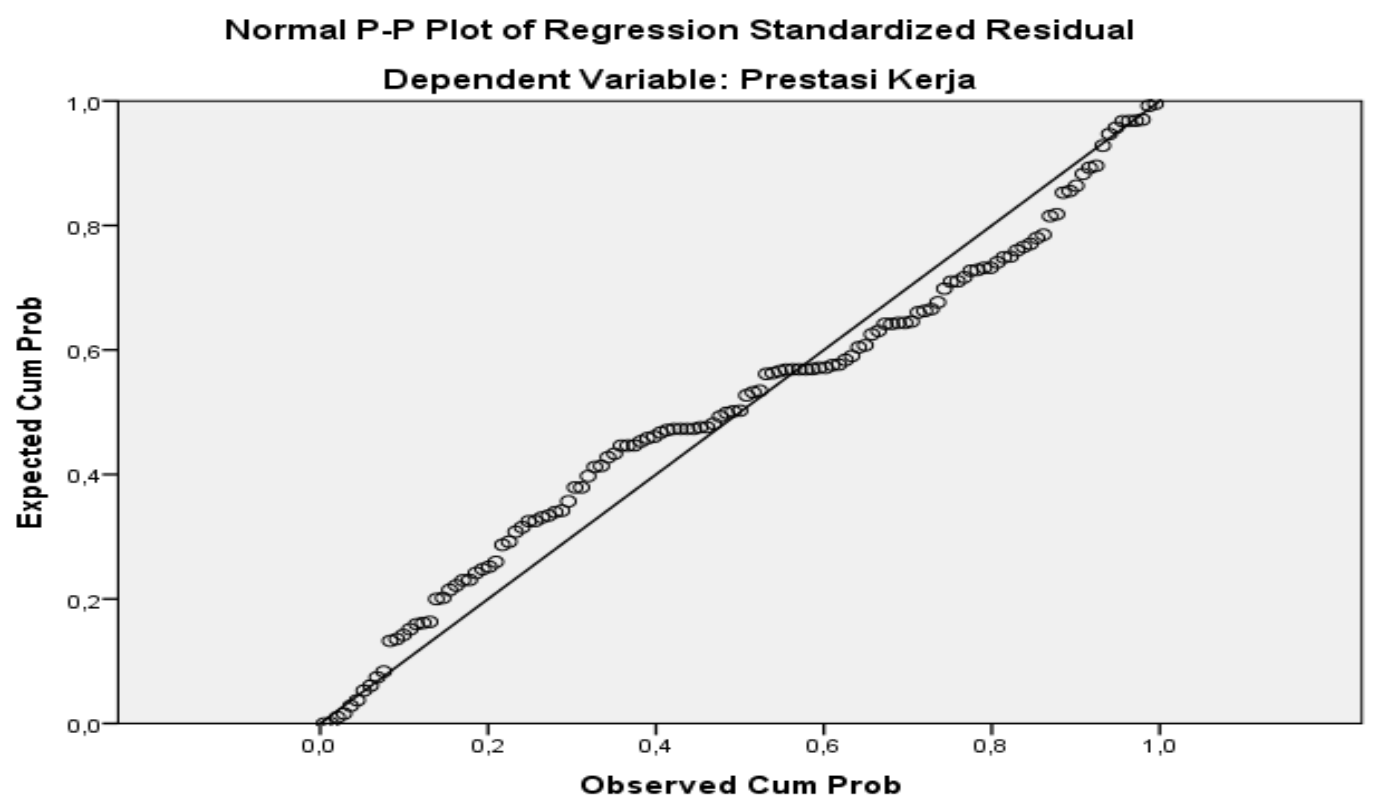


b. Uji Multikolinearitas

Uji multikolinearitas bertujuan untuk menguji apakah pada model ditemukan adanya korelasi antar variabel bebas. Multikolinearitas terjadi jika nilai tolerance $\leq 0,10$ dan VIF (Variance Inflation Factor) $\geq 10$ (Ghozali,2009). Uji multikolinearitas terhadap data yang digunakan dalam penelitian ini disajikan dalam tabel 3 berikut ini:

Tabel 3

Hasil Pengujian Multikolinearitas Data

\begin{tabular}{|l|c|c|}
\hline \multirow{2}{*}{\multicolumn{1}{c|}{ Model }} & \multicolumn{2}{|c|}{ Collinearity Statistics } \\
\cline { 2 - 3 } & Tolerance & VIF \\
\hline nnstant) & & \\
mitmen Afektif & 0,613 & 1,631 \\
mitmen Berkelanjutan & 0,722 & 1,385 \\
mitmen Normatif & 0,765 & 1,308 \\
\hline
\end{tabular}

Sumber : Hasil pengolahan data 2020 SPSS

Tabel diatas menunjukkan bahwa nilai tolerance untuk semua variabel independen $\geq 0,1$ dan nilai VIF $\leq 10$. Jadi dapat disimpulkan bahwa tidak ada multikolinearitas antar variabel independen dalam model regresi.

c. Uji Heteroskedastisitas

Uji heterodekastisitas bertujuan untuk menguji apakah dalam model regresi terjadi kesamaan variance dari residual satu pengamatan ke pengamatan yang lain (Ghozali, 2009). Model regresi yang baik adalah homokedastisitas atau yang tidak memiliki heterodekastisitas.

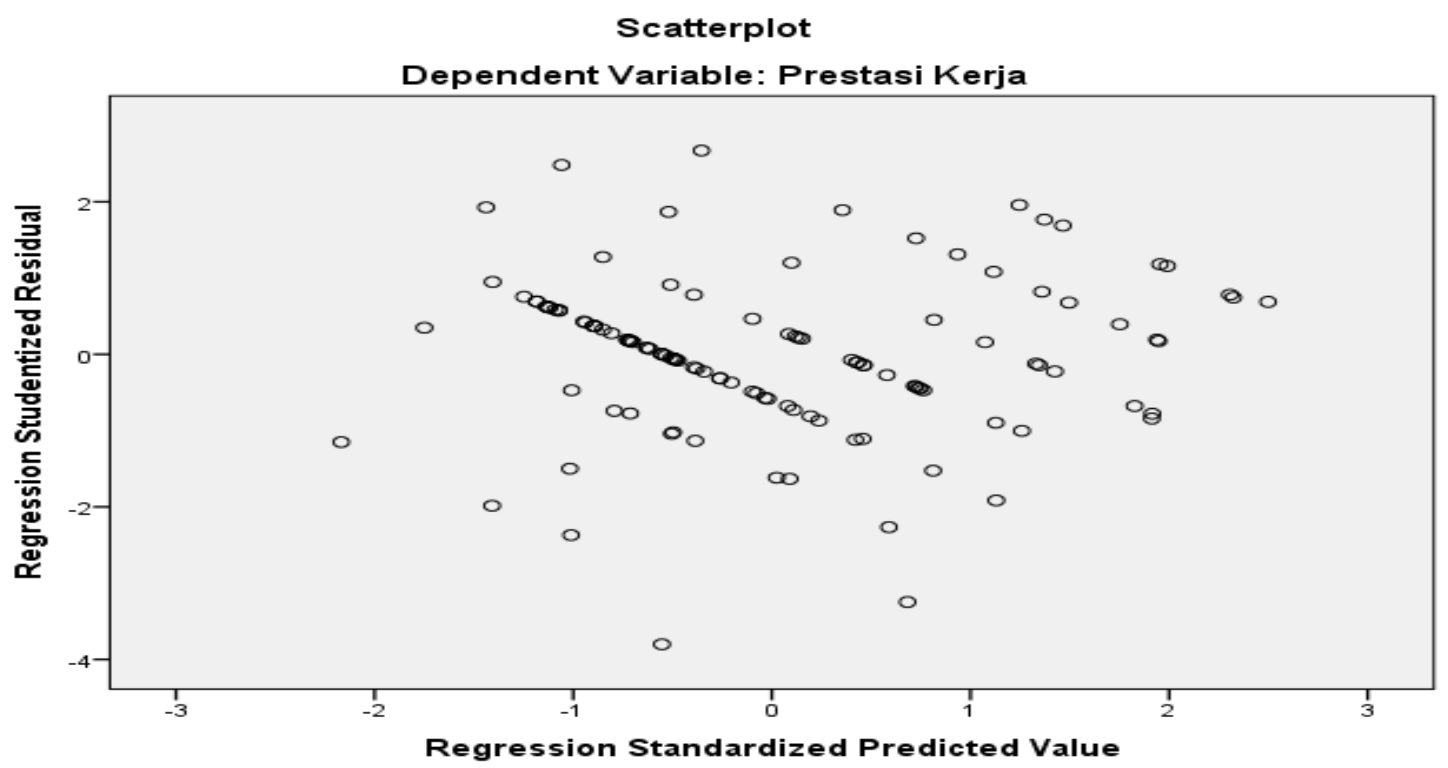


Gambar 2

\section{Grafik Scatterplot}

Dari grafik scatterplot diatas terlihat bahwa titik-titik menyebar secara acak serta tersebar baik diatas maupun dibawah angka 0 pada sumbu Y. Hal ini dapat disimpulkan bahwa tidak terjadi heterokedastisitas pada model regresi, sehingga model regresi layak dipakai untuk memprediksi Prestasi Kerja Tenaga Pendidik.

4) Uji Regresi dengan Uji Selisih Nilai Mutlak

Analisis regresi bertujuan untuk mengukur kekuatan hubungan antara dua variabel atau lebih, juga menunjukkan arah hubungan antara variabel dependen dengan variabel independen.

Variabel moderating adalah variabel yang akan memperkuat atau memperlemah hubungan antara variabel independen terhadap variabel dependen. Dalam penelitian ini yang menjadi model moderating adalah Organization Behavior Citizenship (OCB) dan untuk menguji regresi dengan variabel moderating tersebut menggunakan uji selisih nilai mutlak.
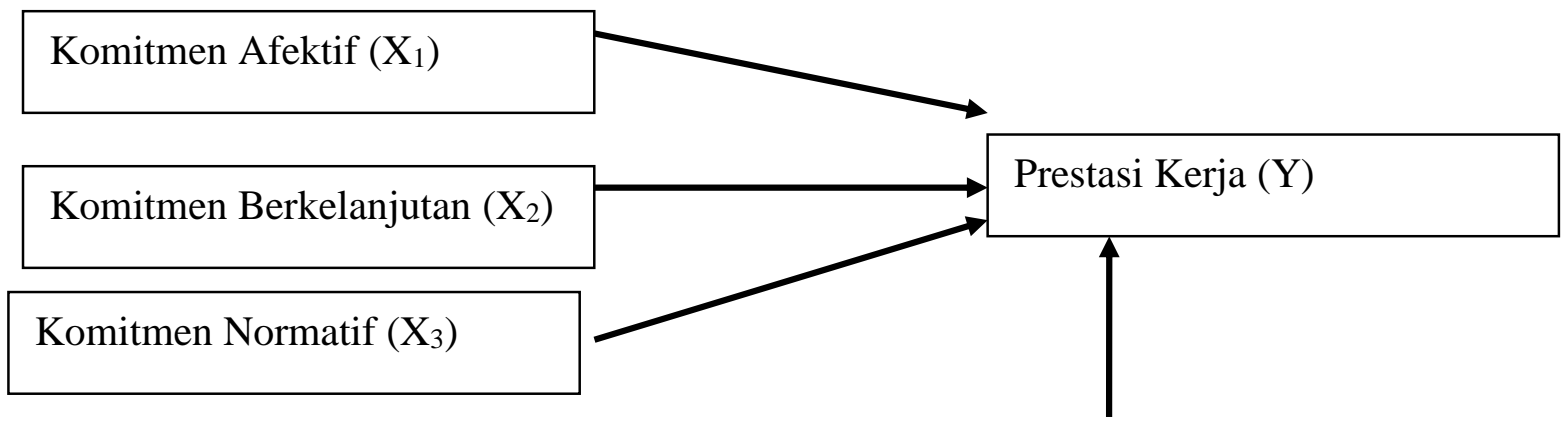

Organization Citizenship Behavior (M)

Gambar 3

Model Moderating

Tabel 4

Hasil Uji Nilai Selisih Mutlak

\section{Coefficients $^{\mathrm{a}}$}

\begin{tabular}{|c|c|c|c|c|c|c|}
\hline & $\begin{array}{l}\text { Unstandard } \\
\text { Coefficient }\end{array}$ & ized & $\begin{array}{l}\text { Standardize } \\
\mathrm{d} \\
\text { Coefficients }\end{array}$ & & & $\begin{array}{l}\text { Collineari } \\
\text { ty } \\
\text { Statistics }\end{array}$ \\
\hline Model & B & Std. Error & Beta & $\mathrm{t}$ & Sig. & $\begin{array}{l}\text { Toleranc } \\
\mathrm{e}\end{array}$ \\
\hline $1 \quad$ (Constant) & 11,790 & 180 & & 65,650 & 000 & \\
\hline
\end{tabular}




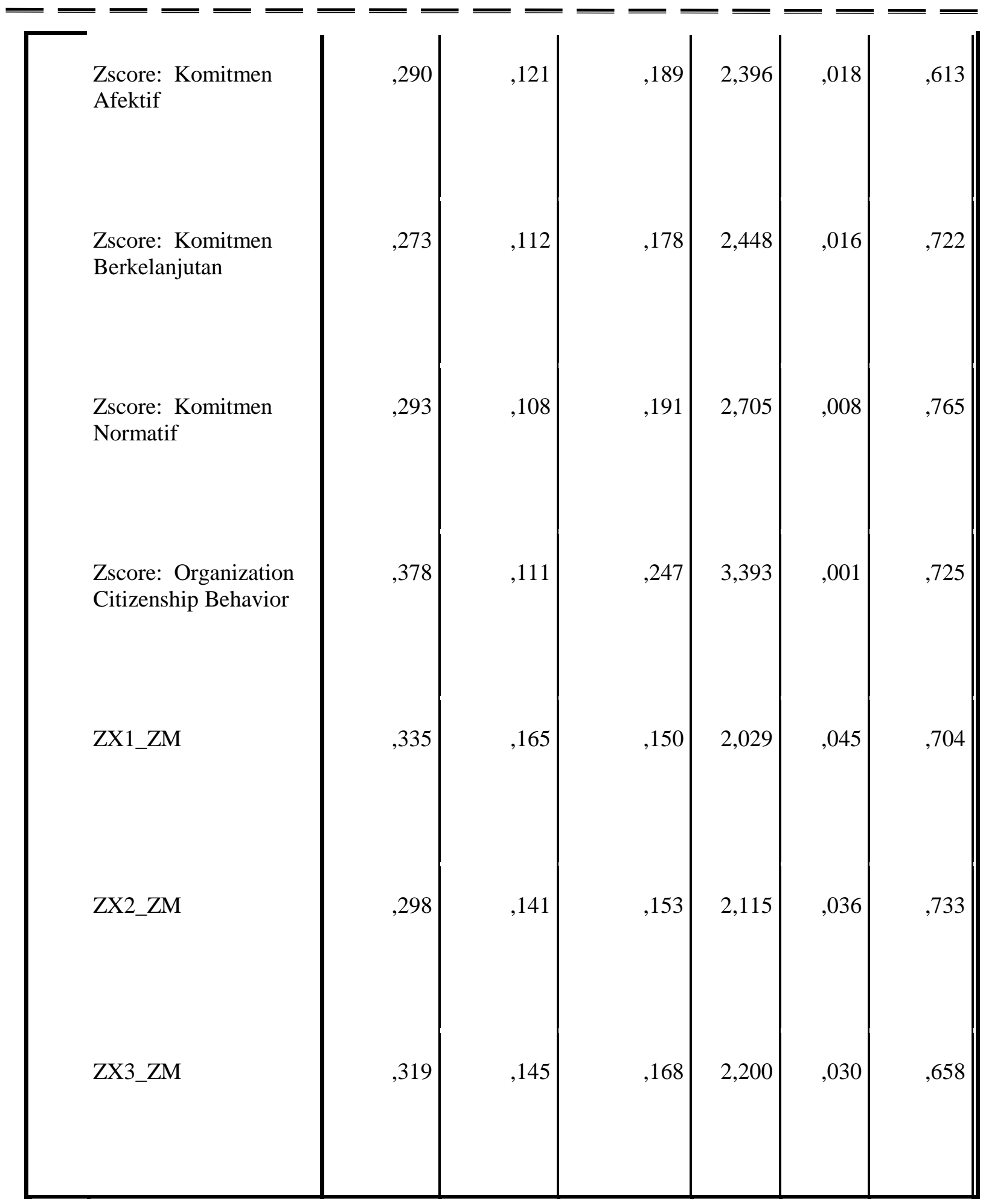

a. Dependent Variable: Prestasi Kerja

Sumber : Hasil pengolahan data 2020 SPSS

Dari hasil uji nilai diatas, konstanta dan koefisien regresi yang diperoleh apabila dimasukkan pada persamaan umum regresi adalah sebagai berikut :

$\mathrm{Y}=11,790+0,290 \mathrm{X} 1+0,273 \mathrm{X} 2+0,293 \mathrm{X} 3+0,335 \mathrm{ZX} 1 \_\mathrm{ZM}+0,298 \mathrm{ZX} 2 \_\mathrm{ZM}+$ 0,319 ZX3_ZM + e 
Koefisien regresi konstant diketahui sebesar 11,790 Koefisien regresi variabel komitmen afektif diketahui sebesar 0,290 dan bernilai positif. Koefisien regresi variabel komitmen berkelanjutan diketahui sebesar 0,273 dan bernilai positif. Koefisien regresi variabel komitmen normatif diketahui sebesar 0,293 dan bernilai positif. Koefisien regresi variabel komitmen afektif dimoderasi organization citizenship behavior diketahui sebesar 0,335 dan bernilai positif. Koefisien regresi variabel komitmen berkelanjutan dimoderasi organization citizenship behavior diketahui sebesar 0,298 dan bernilai positif. Koefisien regresi variabel komitmen normatif dimoderasi organization citizenship behavior diketahui sebesar 0,319 dan bernilai positif.

5) Uji Hipotesis

a. Uji t

Berdasarkan nilai signifikansinya dari tabel coefficients diatas diperoleh nilai signifikansi $\mathrm{X}_{1}$ sebesar $0,018<0,05$ sehingga dapat disimpulkan bahwa variabel komitmen afektif $\left(\mathrm{X}_{1}\right)$ berpengaruh berpengaruh terhadap variabel prestasi kerja $(Y)$, nilai signifikansi $\mathrm{X}_{2} 0,016<0,05$ sehingga dapat disimpulkan bahwa komitmen berkelanjutan berpengaruh terhadap variabel prestasi kerja (Y), nilai signifikansi $\mathrm{X}_{3} 0,008<0,05$ sehingga dapat disimpulkan bahwa komitmen normatif berpengaruh terhadap variabel prestasi kerja $(\mathrm{Y})$.

Komitmen afektif, berkelanjutan dan normatif berpengaruh terhadap prestasi kerja dimana komitmen afektif tenaga pendidik memiliki keterikatan emosional, identifikasi tenaga pendidik dan keterlibatan tenaga pendidik pada organisasi, untuk komitmen berkelanjutan melibatkan pengorbanan pribadi (investasi) apabila meninggalkan organisasi dan komitmen normatif tenaga pendidik wajib bertahan dalam organisasi.

\section{b. Uji F}

Uji statistik F pada dasarnya menunjukkan apakah semua variabel independent atau bebas yang dimasukkan dalam model mempunyai pengaruh secara bersama-sama terhadap variabel dependent atau terikat (Ghozali, 2011: 98). Pengujian ini untuk menguji apakah terdapat pengaruh komitmen organisasi terhadap prestasi kerja dengan OCB sebagai variabel moderating secara simultan. Hasil uji statistik F dapat dilihat pada tabel 5 berikut :

Tabel 5

Hasil Uji Statistik F

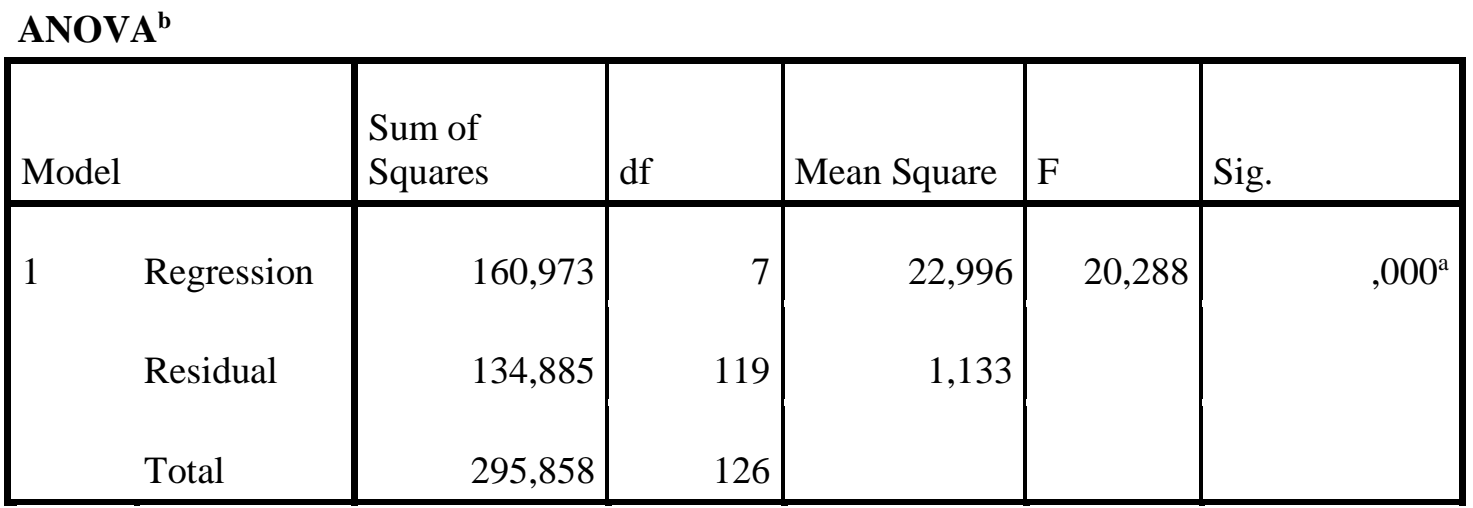

a. Predictors: (Constant), ZX3_ZM, Zscore: Komitmen Normatif, ZX2_ZM, Zscore: Organization Citizenship Behavior, Zscore: Komitmen Berkelanjutan, ZX1_ZM, Zscore: Komitmen Afektif 
b. Dependent Variable: Prestasi Kerja

Sumber : Hasil pengolahan data 2020 SPSS

Pada tabel 5 di atas dapat dilihat bahwa hasil uji statistik $\mathrm{F}$ adalah 20,288 dan nilai signifikansinya adalah 0,000 karena nilai signifikansinya lebih kecil dari 0,05 atau $(0,000<$ 0,05). Hasil uji statistik (F) dapat disimpulkan bahwa model dalam penelitian ini baik.

6) Koefisien Determinasi

Koefisien determinasi $\left(\mathrm{R}^{2}\right)$ menunjukkan seberapa besar pengaruh variabel bebas (independent) terhadap variabel terikat (dependent) yang dinyatakan dalam presentase (\%). Nilai koefisien determinasi $\left(\mathrm{R}^{2}\right)$ dalam penelitian ini dapat dilihat pada tabel 6 berikut :

\section{Tabel 6}

\section{Hasil Uji Koefisien Determinasi}

\begin{tabular}{|c|c|c|c|c|}
\hline \multicolumn{5}{|c|}{ Model Summary $^{\mathbf{b}}$} \\
\hline Model & $\mathrm{R}$ & R Square & $\begin{array}{l}\text { Adjusted R } \\
\text { Square }\end{array}$ & $\begin{array}{l}\text { Std. Error of } \\
\text { the Estimate }\end{array}$ \\
\hline 1 &, $738^{\mathrm{a}}$ &, 544 &, 517 & 1,065 \\
\hline
\end{tabular}

a. Predictors: (Constant), ZX3_ZM, Zscore: Komitmen Normatif, ZX2_ZM, Zscore: Organization Citizenship Behavior, Zscore: Komitmen Berkelanjutan, ZX1_ZM, Zscore: Komitmen Afektif

b. Dependent Variable: Prestasi Kerja

Sumber : Hasil pengolahan data 2020 SPSS

Nilai koefisien determinasi $\left(\mathrm{R}^{2}\right)$ pada tabel 5.16 menunjukkan nilai Adjusted $\mathrm{R}^{2}$ sebesar 0,517 sebesar 51,7\% sedangkan sisanya 48,3\% dipengaruhi oleh faktor-faktor lain di luar variabel yang diteliti.

\section{PEMBAHASAN}

1. Bahwa adanya peningkatan pada Komitmen Afektif yang ditunjukkan Tenaga Pendidik maka akan semakin meningkatkan Prestasi Kerja Tenaga Pendidik SMK Swasta Kota Salatiga.

2. Berdasarkan dari hasil yang didapat ini dapat ditarik kesimpulan bahwa adanya peningkatan pada Komitmen Berkelanjutan yang ditunjukkan Tenaga Pendidik maka akan semakin meningkatkan Prestasi Kerja Tenaga Pendidik SMK Swasta Kota Salatiga.

3. Berdasarkan dari hasil yang didapat ini dapat ditarik kesimpulan bahwa adanya peningkatan pada Komitmen Normatif yang ditunjukkan Tenaga Pendidik maka akan semakin meningkatkan Prestasi Kerja Tenaga Pendidik SMK Swasta Kota Salatiga.

4. Hasil analisis selisih mutlak memperlihatkan bahwa pengaruh Komitmen Afektif, Komitmen Berkelanjutan dan Komitmen Normatif terhadap Prestasi Kerja melalui Organization Citizenship 
Behavior (OCB) dapat menjadi varibel yang memoderasi pengaruh Komitmen Afektif, Komitmen Berkelanjutan dan Komitmen Normatif terhadap Prestasi Kerja. Dengan hasil ini maka dapat disimpulkan OCB dapat menjadi variabel yang memoderasi antara Komitmen Afektif, Komitmen Berkelanjutan dan Komitmen Normatif terhadap Prestasi Kerja.

\section{PENUTUP}

\section{Simpulan}

Hasil penelitian menunjukkan bahwa Komitmen Afektif, Normatif dan Berkelanjutan berpengaruh positif terhadap Prestasi Kerja, Organization Citizenship Behavior $(O C B)$ berpengaruh positif terhadap Prestasi Kerja serta Organization Citizenship Behavior $(O C B)$ memperkuat hubungan positif antara Komitmen Afektif, Normatif dan Berkelanjutan terhadap Prestasi Kerja sehingga dapat disimpulkan bahwa Organization Citizenship Behavior $(O C B)$ yang dimiliki oleh Tenaga Pendidik pada SMK Swasta Kota Salatiga mampu memperkuat hubungan positif antara Komitmen Organisasi Terhadap Prestasi Kerja.

\section{Saran}

Saran yang bisa disampaikan berdasarkan dari hasil penelitian yang didapat, adalah sebagai berikut :

1. Tenaga Pendidik perlu untuk lebih ditingkatkan dari segi keterlibatan dan kesetiaan karyawan pada organisasi dalam hal ini adalah Tenaga Pendidik agar bersedia terlibat dalam kegiatan pekerjaannya baik yang terstuktur maupun tidak juga kesetiaan terhadap organisasinya dalam hal ini adalah Sekolah yang menjadi tempat dimana Tenaga Pendidik ini mengajar.

2. Organization Citizenship behavior $(O C B)$ yang ditunjukkan para Tenaga Pendidik perlu ada peningkatan karena dari indikator tersebut tidak pernah mengeluh tentang tugas dan kebijakan ditempat mereka bekerja. Hal ini perlu disikapi dengan lebih memperat jalinan komunikasi dan gaya kepemimpinan yang penuh kekeluargaan di antara pimpinan sekolah terhadap tenaga pendidik.

\section{UCAPAN TERIMAKASIH}

Pada kesempatan ini, peneliti ingin mengucapkan terima kasih yang sedalam- dalamnya kepada berbagai pihak yang telah membantu terwujudnya penelitian ini:

1. DIKTI yang telah memberikan bantuandana kepada peneliti untuk melaksanakan penelitian ini.

2. Ibu Hj. Fudji Sri Mar'ati, SE., M.Si selaku Ketua STE AMA Salatiga yang memberi arahan kepada tim peneliti.

3. Ibu Rina Sari Qurniawati, SE., M.Sc sebagai Kepala Penelitian, Pengabdian dan Pemberdayaan Masyarakat (P3M) STIE AMA Salatiga atas dukungan yang diberikan.

4. Kepala Sekolah SMK Saraswati, SMK Muhammadiyah dan SMK PGRI 2 Kota Salatiga.

Penelitian ini masih jauh dari sempurna, oleh karena itu kritik dan saran sangat diharapkan guna memperbaiki laporan ini dan semoga laporan ini dapat diterima dengan baik.

\section{DAFTAR PUSTAKA}

\section{Buku Bahasa Indonesia}

A.A. Anwar Prabu Mangkunegara. 2009. Manajemen Sumber Daya Manusia.Bandung:PT. Remaja Rosdakarya. 
Ghozali, Imam. 2006.Aplikasi Analisis Multivariate dengan Program SPSS. Edisi Ketiga.Semarang:Badan Penerbit Universitas Diponegoro.

Meyer, J.P.et al. (2002), Afective, Continuance and Normative to the Organization: A Meta-analysis of Antecendent, Correlate, and Consequences, Journal of Vocational Behavior.

Robbins SP, dan Judge. 2008. Perilaku Organisasi Buku 2, Jakarta: Salemba Empat

Sudarmanto, 2014, Kinerja dan Pengembangan Kompetensi SDM, PustakaPelajar, Yogyakarta

Sugiyono Prof. Dr., 2010. Metode Penelitian Pendidikan Pendekatan Kuantitatif, Kualitatif dan $R \&$ D, Bandung: CV. Alfabeta

Sugiyono. (2012). Metode Penelitian Kuantitatif, Kualitatif, dan R\&D.Cetakan ke-17. Bandung:Alfabeta.

\section{Jurnal :}

Anita Widia MY, 2018.Pengaruh Komitmen Afektif, Komitmen Berkelanjutan, Dan Komitmen Normatif Terhadap Prestasi Kerja Karyawan Pada PT BPR. Dinamika Bangun Arta Salatiga. STIE AMA Salatiga.

Luluk Nur Aisyah, 2018.Pengaruh Kepemimpinan Transformasional, Komitmen Organisasional, Dan Kepuasan Kerja Terhadap Organizational Citizenship Behavior. STIE AMA Salatiga. 